\title{
UJI ORGANOLEPTIK ENHALUS TEA BERDASARKAN CARA PENGERINGAN DAN TINGKAT KETUAAN DAUN SECARA MORFOLOGI
}

\author{
Shofia Nur Inayah ${ }^{1}$, Wa Nurul Mutmainah Jainudin Heremba ${ }^{2}$, Yordan Samloy ${ }^{3}$, Prelly \\ M.J. Tuapattinay $\mathbf{a}^{4^{*}}$ \\ ${ }^{123}$ Mahasiswa Pendidikan Biologi, Fakultas Keguruan dan Ilmu Pendidikan, Universitas \\ Pattimura \\ ${ }^{4}$ Dosen Pendidikan Biologi, Fakultas Keguruan dan Ilmu Pendidikan, Universitas Pattimura
}

*Corresponding author: Prelly M. J. Tuapattinaya

inayahnurshofia@gmail.com

\begin{abstract}
ABSTRAK. Provinsi Maluku adalah salah satu wilayah kepulauan di Indonesia dengan luas perairan yang dominan sekitar $90 \%$. Salah satu wilayah di Maluku, yaitu di Desa Suli yang memiliki hamparan lamun yang cukup luas, meliputi lamun Enhalus acoroides dan Thalassia hemprichii. Berdasarkan kelimpahan lamun di wilayah tersebut maka dapat dimanfaatkan menjadi suatu inovasi baru yang bermanfaat bagi masyarakat, seperti diolah menjadi produk teh yang bermanfaat. Pembuatan teh tidak lepas dari proses pengeringan. Pengeringan daun teh dengan diangin-anginkan dan menggunakan oven. Kualitas teh dipengaruhi juga oleh ketuaan daun dan metode pengolahannya. Tujuan penelitian ini, yaitu untuk mengetahui karakteristik sifat hedonik dan sensori yang meliputi rasa, warna dan aroma Enhalus Tea sebagai pangan alternatif masyarakat pesisir. Penelitian ini merupakan penelitian deskriptif, Pengambilan sampel daun lamun di perairan Desa Suli, pembuatan teh daun lamun (Enhalus Tea) dan pengujian sifat hedonik dan sifat sensori dilaksanakan di Laboratorium. Hasil pengujian hedonik aroma, panelis menyukai Enhalus Tea formula A1B1 (daun muda-dianginkan), formula A3B1 (daun tua-dianginkan), formula A1B2 (daun muda-oven) dan formula A2B2 (daun setengah tua-oven), sedangkan pada Enhalus Tea formula A2B1 (daun setengah tua-dianginkan) dan formula A3B2 (daun tua-oven) panelis kurang suka dengan aroma teh tersebut. Berdasarkan analisis data pada uji deskripsi sensori aroma kuat dimiliki oleh sampel A2B1 (daun setengah tua-dianginkan). Penilaian warna pada semua sampel rerata berada di tingkat 1 yaitu hijau kekuningan, sedangkan penilaian rasa terkuat pada sampel A2B1 (daun setengah tua-dianginkan).
\end{abstract}

Kata Kunci: Enhalus Tea, Pengeringan, Hedonik, Sensori.

ABSTRACT. Moluccas is one of the islands in Indonesia with dominant water area of around 90\%. One area in Moluccas, namely the Suli Village which has a wide expanse of seagrass, two of them are seagrasses Enhalus acoroides and Thalassia hemprichii. Based on the abundance of seagrass in the area, it can be utilized as a new innovation in which beneficial to the community, such as processed into useful tea products. Tea making cannot be separated from the drying process. Dry the tea leaves by aerating and using an oven. The quality of tea is also affected by the aging of the leaves and its processing method. The purpose of this study, namely to determine the characteristics of hedonic and sensory properties which include the taste, color and aroma of Enhalus Tea as an alternative food for coastal communities. This research is a descriptive study, sampling seagrass leaves in the waters of Suli Village, making seagrass tea (Enhalus Tea) and testing the nature of hedonic and sensory properties carried out in the Laboratory. The results shows that panelists liked Enhalus Tea formula A1B1 (young-aerated leaves), formula A3B1 (oldaerated leaves), formula A1B2 (young-oven leaves) and A2B2 formula (half-aged-oven leaves), and didn't liked the tea aroma of Enhalus Tea A2B1 formula (half-old-aerated leaves) and A3B2 formula (old-ovenleaf). Based on the data analysis on the sensory description test the strong aroma is owned by A2B1 samples (half-old-aerated leaves). The color assessment of all the mean samples was at level 1 is yellowish green, while the strongest flavor assessment was on the A2B1 sample (half-old-aerated leaves).

Keywords : Enhalus Tea, Drying, Hedonic, Sensory 


\section{Pendahuluan}

Indonesia merupakan negara kepulauan yang sebagian besar wilayahnya berupa perairan. Provinsi Maluku adalah salah satu wilayah kepulauan di Indonesia dengan luas perairan yang dominan sekitar 90\%. Kondisi alam yang didominasi lautan merupakan kekuatan atau potensi lokal bagi pengembangan wilayah yang berbasis pada kearifan lokal. Salah satu wilayah di Maluku, yaitu di Desa Suli, Kecamatan Salahutu, Kabupaten Tengah yang memiliki hamparan lamun yang cukup luas. Phillips dan Milchakova (2003) mendefenisikan lamun sebagai tanaman monokotil yang unik karena tenggelam dalam air, memiliki sistem akar dengan batang terkubur dalam substrat lunak, reproduksi vegetatif dan seksual, serta memiliki buah yang dibuahi oleh serbuk sari melalui perantaraan air. Perairan desa Suli merupakan salah satu habitat bagi padang lamun. Penelitian Tuapattinaya (2014) melaporkan bahwa terdapat tujuh jenis lamun di perairan pantai desa Suli yaitu jenis lamun Cymodocea serrulata, Cymodoceae rotundata, Enhalus acoroides, Halodule uninervis, Halophila ovalis, Thalasia hemprichii, dan Syringodium isoetifolium. Sementara itu, menurut Padang (2011) lamun Enhalus acoroides dan Thalassia hemprichii merupakan jenis lamun yang dominan tersebar di perairan desa Suli.

Lamun E. acoroides telah populer di kalangan masyarakat pesisir, khususnya masyarakat di desa Suli. Kebiasaan masyarakat adalah mengkonsumsi biji lamun menjadi pangan alternatif. Sedangkan beberapa penelitian menunjukkan bahwa biji lamun E. acoroides dapat diolah menjadi susu nabati (Muskita dan Tuapattinaya, 2016; Latuihamallo, dkk., 2019) dan tempe biji lamun (Tuapattinaya, et al., 2018). Fakta menunjukkan bahwa masyarakat lebih tertarik memanfaatkan biji lamun, sedangkan E. acoroides juga memiliki bagian lain seperti rhizoma dan daun lamun. Menurut Irawan dan Matuankotta (2015), Enhalus acoroides merupakan jenis lamun dengan karakter daun yang khas yaitu menyerupai pita lebar dengan panjang sekitar $2 \mathrm{~m}$ berbeda dengan jenis lamun yang lainnya Oleh karena itu, daun lamun $E$. acoroides yang dominan dan mudah diperoleh tanpa mengenal musim dibandingkan dengan buahnya, maka daun lamun dapat diolah dan dimanfaatkan juga menjadi bahan pangan.

Selama ini masyarakat mengenal minuman teh yang merupakan hasil olahan dari daun teh (Camellia sinensis). Namun beberapa penelitian juga membuktikan bahwa teh dapat dibuat dari jenis daun tanaman lain. Minuman teh dapat berasal dari daun sukun, daun kelor, dan daun sirsak (Maharani, dkk., 2012; Wahyudi, dkk., 2019; Adri dan Hersoelistyorini, 2013). Oleh karena itu, minuman teh berbahan dasar daun lamun Enhalus acoroides juga dapat dijadikan minuman alternatif pengganti minuman teh dari daun Camellia sinensis. Hal ini menunjukkan bahwa daun lamun E. acoroides dapat diolah menjadi teh lamun (Enhalus Tea).

Pembuatan teh tidak lepas dari proses pengolahan yaitu pengeringan. Pengeringan daun teh memiliki cara yang bervariasi, diantaranya pengeringan dengan diangin-anginkan dan pengeringan menggunakan oven (Somantri dan Tantri, 2011). Mudau dan Ngezimana (2014) melaporkan bahwa kadar fenolik teh semak Athrixia phylicoides dengan metode pengeringan menggunakan kering beku dan kering teduh lebih tinggi dibandingkan dengan metode pengeringan oven dan kering matahari. Menurut Angraiyati dan Hamzah (2017) tujuan pengeringan yaitu mengurangi kandungan kadar air pada bahan pangan sehingga dapat menghambat pertumbuhan mikroba yang tidak diinginkan. Proses pengeringan mengakibatkan menurunnya zat aktif yang terkandung dalam suatu bahan pangan (Winarno, 2002). Sehingga proses pengeringan juga menentukan kualitas teh, metode pengeringan yang berbeda dapat mempengaruhi karakteristik fisik dan kualitas dari teh tersebut.

Selain proses pengeringan, kualitas teh juga dipengaruhi oleh ketuaan daun. Felicia, dkk. (2016) melaporkan bahwa ketuaan daun berpengaruh pada kandungan dan jenis flavonoidnya, sehingga teh yang terbuat dari daun tua alpukat memiliki nilai rata-rata total flavonoid lebih tinggi dibandingkan dengan daun muda yaitu 54,08 mgQE/g bk bahan dan 33,54 mgQE/g bk bahan. Hasil yang sama juga disampaikan oleh Tehubijuluw, dkk (2018) bahwa minuman teh yang berasal dari daun lamun Enhalus acoroides yang tua memiliki kadar flavonoid yang tinggi $(0.1623 \%)$, sedangkan minuman teh daun lamun yang muda mempunyai kadar flavonoid yang rendah $(0.0888 \%)$. Oleh karena kandungan flavonoid yang tinggi di daun tua menyebabkan teh berasa pahit. Mahmood et.al., (2010) menambahkan bahwa kadar flavonoid yang tinggi dalam teh berkontribusi dalam sensasi rasa pahit pada teh.

Untuk mendapatkan penerimaan tentang kesukaan konsumen pada Enhalus tea, maka dilakukan pengujian organoleptik atau sensori terhadap produk pangan inovatif tersebut. Menurut Wahyuningtias (2010) uji organoleptik atau biasa disebut uji indera atau uji sensori merupakan cara pengujian dengan menggunakan indera manusia sebagai alat utama untuk pengukuran daya penerimaan terhadap produk. Pengujian organoleptik mempunyai peranan penting dalam penerapan mutu Enhalus Tea ini. 
Hasil dari uji organoleptik ini dapat menjadi acuan untuk diversifikasi Enhalus Tea menjadi minuman teh yang dikonsumsi oleh masyarakat pesisir dan non pesisir. Diversifikasi terhadap Enhalus Tea perlu dilakukan untuk lebih meningkatkan potensi gizi dan senyawa aktif yang terkandung dalam produk Enhalus Tea. Sehingga Enhalus Tea akan lebih mempunyai nilai tambah baik dari segi citarasa maupun manfaatnya dalam menjaga kesehatan tubuh manusia. Tujuan dari penelitian ini adalah menganalisis organoleptik Enhalus Tea berdasarkan cara pengeringan dan tingkat ketuaan daun secara morfologi.

\section{Metode}

\section{Pengambilan Sampel}

Pengambilan sampel daun lamun di perairan Desa Suli. Pembuatan teh daun lamun (Enhalus Tea) dan pengujian sifat hedonik dan sifat sensori dilaksanakan di Laboratorium Biologi Dasar FKIP Universitas Pattimura Ambon. Waktu pengambilan sampel pada tanggal 13 Juni 2019 dan pembuatan Enhalus Tea serta pengujian sifat hedonik dan sensorik berlangsung pada tanggal 14-17 Juni 2019. Alat dan bahan yang digunakan dalam penelitian ini adalah penampan, pisau, timbangan analitik, saringan, hot plate, gelas ukur, gelas kimia, blender, oven, kipas angin, toples, daun lamun (Enhalus acoroides) dan air. Pembuatan Enhalus Tea diadaptasi dari pembuatan teh daun lamun (Harfelein dkk., 2018).

\section{Uji Organoleptik Enhalus Tea}

Uji deskripsi sensori Enhalus Tea meliputi pengujian terhadap aroma, warna dan rasa Enhalus Tea serta menggunakan 20 panelis yang terlatih. Uji deskripsi sensori Enhalus Tea meliputi pengujian terhadap aroma, warna dan rasa Enhalus Tea. Uji sensori menggunakan 20 panelis yang terlatih. Data yang diperoleh ditabulasi dan ditentukan nilai mutunya dengan mencari hasil rerata pada setiap panelis.

\section{Hasil Penelitian}

\subsection{Hasil Olahan Produk Enhalus Tea}

Hasil pengolahan Enhalus tea berdasarkan cara pengeringan dan morfologi daun muda, setengah tua dan tua ditunjukkan pada Gambar 1 berikut ini.

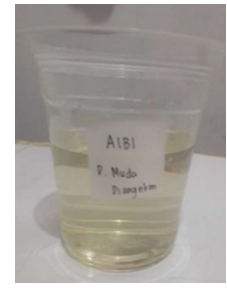

Hasil A1B1 (Dianginkan -Daun Muda)

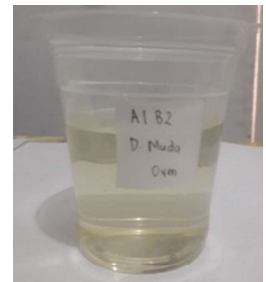

Hasil A1B2 (Oven - Daun Muda)

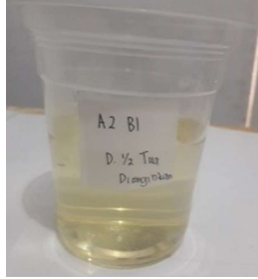

Hasil A2B1 (Dianginkan - Daun Setengah Tua)

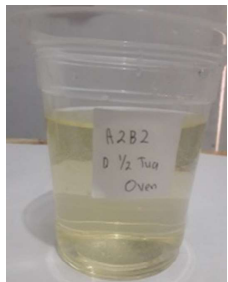

Hasil A2B2 (Oven - Daun Setengah Tua)

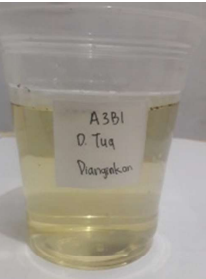

Hasil A3B1 (Dianginkan Daun Tua)

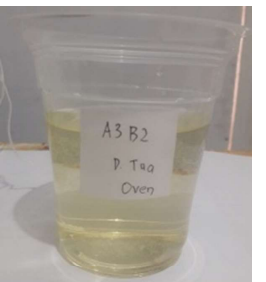

Hasil A3B2 (Oven - Daun

Tua)

Gambar 1. Hasil olahan Enhalus tea berdasarkan cara pengeringan dan morfologi daun 


\subsection{Uji Sensori}

Hasil analisis sifat sensori Enhalus Tea divisualisasikan pada Gambar 2 sampai Gambar 4 berikut ini.

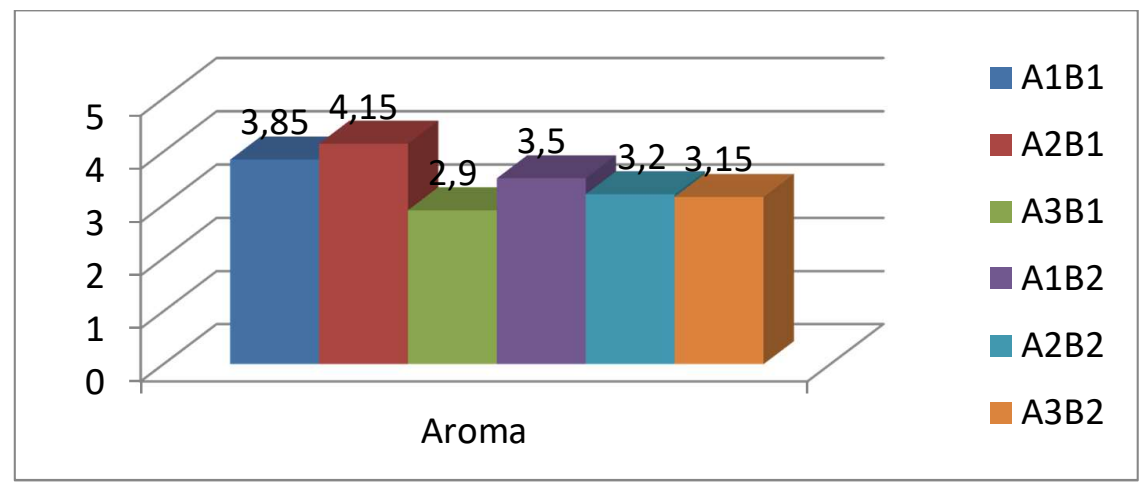

\section{Gambar 2. Uji Sensori Aroma minuman Enhalus Tea Berdasarkan cara pengeringan dan morfologi daun}

Rata-rata minuman Enhalus Tea dengan formula A3B1, A3B2, A2B2 memiliki aroma yang cukup. Sedangkan formula A1B1, A2B1,A1B2 memiliki aroma yang kuat (Grafik 2). Hal ini menunjukkan bahwa formula A1B1, A2B1, A1B2 memiliki aroma khas lamun yang lebih baik dari formula A3B1, A3B2, A2B2.

Aroma merupakan uji organoleptik yang dilakukan menggunakan indra penciuman atau pembauan. Adnan et al (2013) menyatakan bahwa teh dengan jumlah bahan kimia dan volatil yang tinggi memiliki hubungan yang positif terhadap sensorik bau dan rasa. Tingkat ketuaan daun seperti daun muda, setengah tua, dan tua mengandung kadar flavonoid yang berbeda sehinnga mempengaruhi aroma pada minuman Enhalus Tea. Penelitian Felicia dkk (000) menunjukkan bahwa tingkat ketuaan daun alpukat berpengaruh terhadap aroma teh bubuk alpukat. Menurut Ginting, dkk. (2015) tinggi rendahnya nilai aroma teh yang tercium oleh panelis berhubungan dengan kadar ekstrak dalam air teh dan berat teh yang dikandungnya, dimana semakin banyak ekstrak teh dalam air dan semakin berat teh yang digunakan maka semakin banyak aroma teh yang tercium oleh panelis. Menurut standar SNI 03-38362012 aroma yang baik untuk teh adalah normal yaitu harum khas teh. Berdasarkan penelitian ini minuman Enhalus Tea telah memenuhi persyaratan aroma khas daun lamun masih dapat dicium oleh panelis.

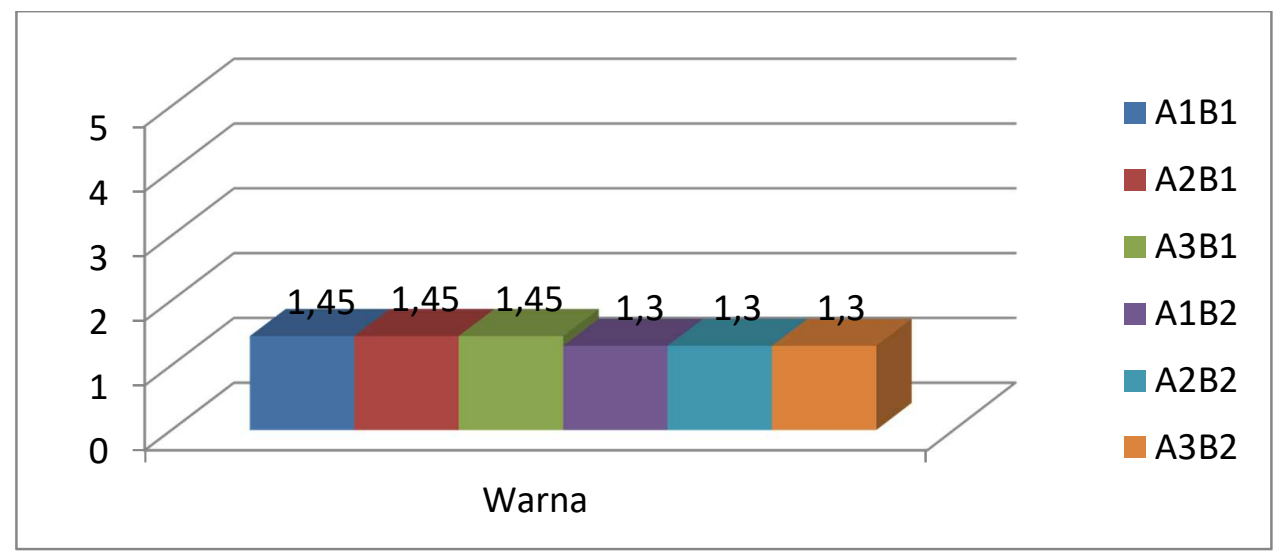

Gambar 3. Uji Sensorik Warna minuman Enhalus Tea Berdasarkan cara pengeringan dan morfologi daun 
Gambar 3. menunjukkan bahwa minuman Enhalus Tea dengan formula A1B1, A2B1, A3B1, A1B2, A2B2 dan A3B2 mempunyai warna kuning-kehijauan. Artinya bahwa minuman Enhalus Tea mempunyai warna khas daun lamun. Kandungan fitokimia dalam daun Enhalus acoroides juga berkontribusi dalam memberikan warna terhadap minuman Enhalus tea. Owuor \& Obanda (2001) melaporkan bahwa komponen teh juga mempengaruhi karakteristik sensorik teh terutama kecerahan warna teh (Owuor \& Obanda 2001).

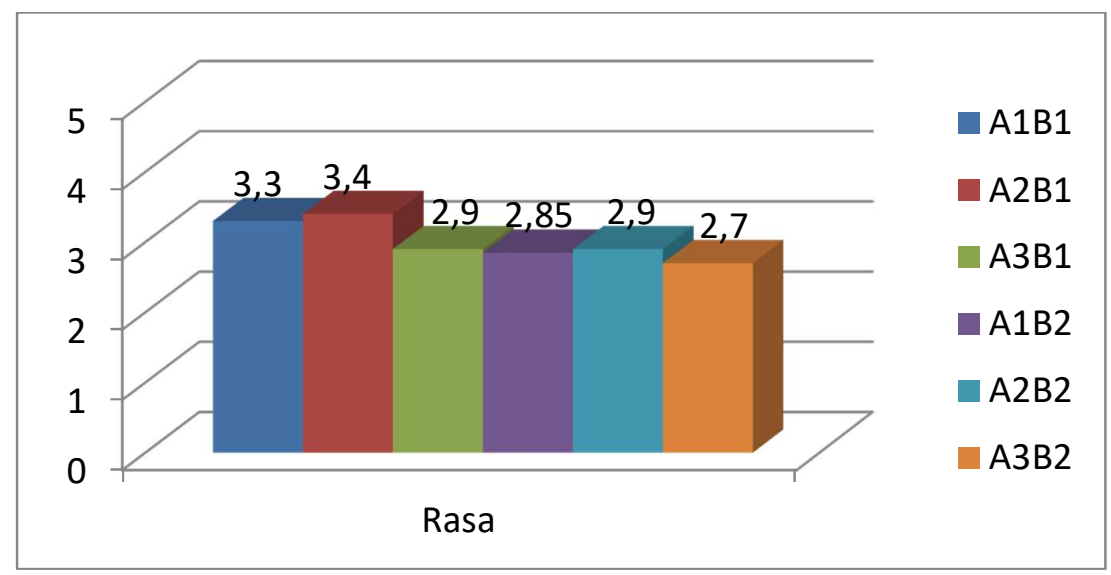

Gambar 4. Uji Sensorik Rasa Enhalus Tea

Rata-rata minuman Enhalus Tea semua formula memiliki rasa yang cukup pahit (Gambar 4). Hal ini menunjukkan bahwa semua formula memiliki rasa yang tidak berbeda.

\subsection{Uji Hedonik (Kesukaan)}

Setelah menganalisis uji sensorik maka langkah selanjutnya adalah analisis tingkat kesukaan (uji hedonik) terhadap minuman Enhalus tea. Hasil analisis uji hedonic divisualisasikanpada Gambar 5 sampai Gambar 7 berikut ini.

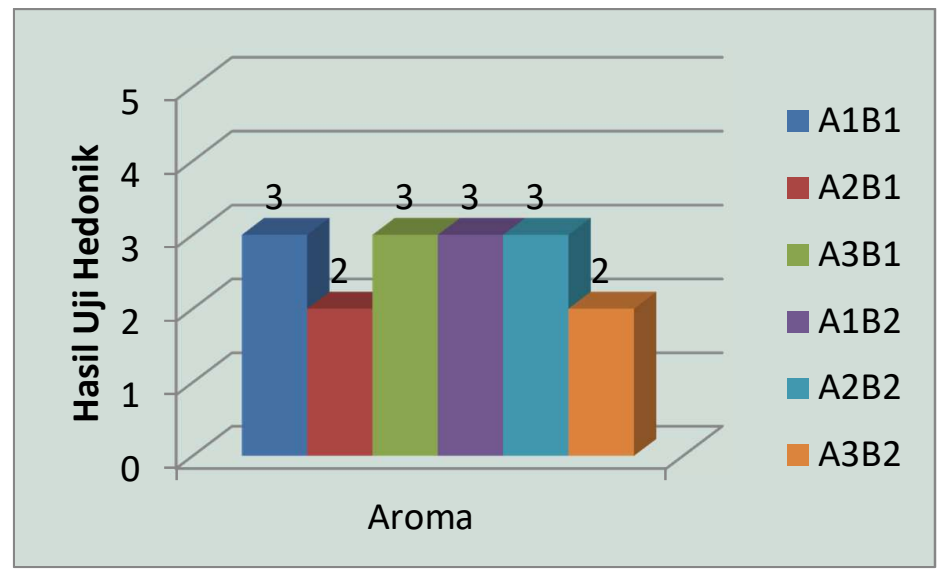

Gambar 5. Uji Hedonik Aroma Enhalus Tea

Hasil analisis uji hedonic menunjukkan bahwa panelis memilih kategori agak suka terhadap aroma minuman Enhalus Tea formula A3B1, A1B1, A1B2, A2B2 dibandingkan dengan formula A2B1 dan A3B2 pada kategori kurang suka (Gambar 5). Hal ini berarti bahwa panelis lebih memilih aroma minuman Enhalus Tea yang berasal dari daun muda dan tua dengan cara pengeringan dianginkan serta daun muda dan setengah tua dengan cara dioven. 


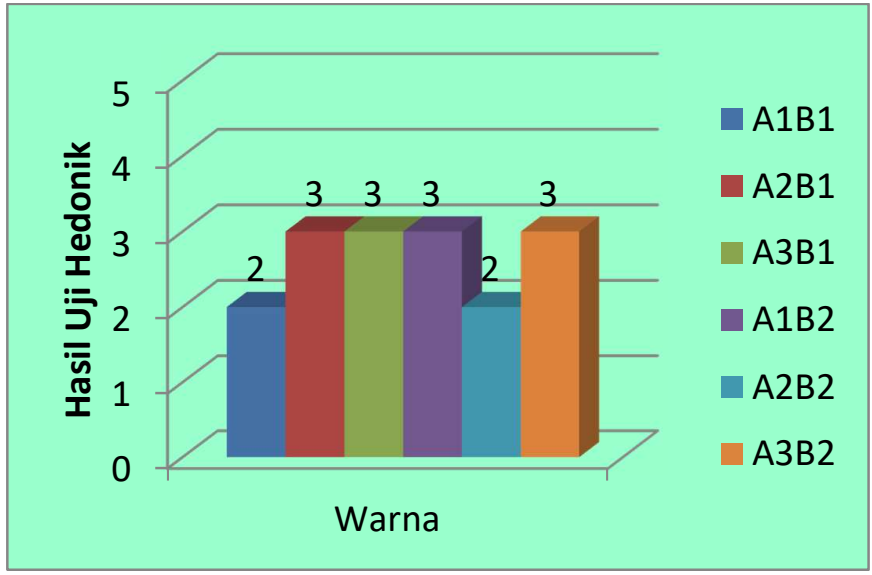

Gambar 6. Uji Hedonik Warna Enhalus Tea

Hasil analisis uji hedonik menunjukkan bahwa panelis memilih kategori agak suka terhadap warna minuman Enhalus Tea formula A2B1, A3B1, A1B2, A3B2 dibandingkan dengan formula A1B1 dan A2B2 pada kategori kurang suka (Gambar 6). Hal ini berarti bahwa panelis lebih memilih warna minuman Enhalus Tea yang berasal dari daun setengah tua dan tua dengan cara pengeringan dianginkan serta daun muda dan tua dengan cara dioven. Menurut Angraiyati dan Hamzah (2017) warna adalah salah satu faktor mutu suatu bahan pangan. Warna merupakan salah satu bagian dari penampakan produk serta parameter penilaian sensori yang penting karena merupakan sifat penilaian sensori yang pertama kali dilihat oleh konsumen. Bila kesan penampakan produk baik atau disukai maka konsumen baru akan melihat sifat penilaian sensori yang lainnya (aroma dan rasa).

Menurut Prabawati dkk. (2015) tingkat intensitas warna teh yang ditimbulkan tergantung dari bahan yang digunakan dan suhu air yang digunakan untuk penyeduhan teh, karena adanya proses penyeduhan akan menyebabkan teh teroksidasi. Sementara itu menurut Saragih (2014) klorofil memiliki gugus phytil ester yang menyebabkan klorofil dapat larut dalam air (polar), panas menyebabkan protein yang terikat didalam lipoprotein akan mengalami denaturasi yang menyebabkan klorofil terbuka dan gugus phytil ester akan larut dalam air. Pendapat yang sama juga disampaikan oleh Li et al (2010) bahwa degradasi pigmen klorofil chlorophy dapat terjadi selama proses pengeringan. Akibat dari degradasi dan larutnya klorofil di dalam air maka minuman Enhalus Tea berwarna hijau kekuningan. Menurut SNI 3836 (2013), warna seduhan teh yang baik adalah khas produk teh. Minuman Enhalus Tea telah memenuhi persyaratan karena warna minuman Enhalus Tea masih menampilkan warna daun lamun.

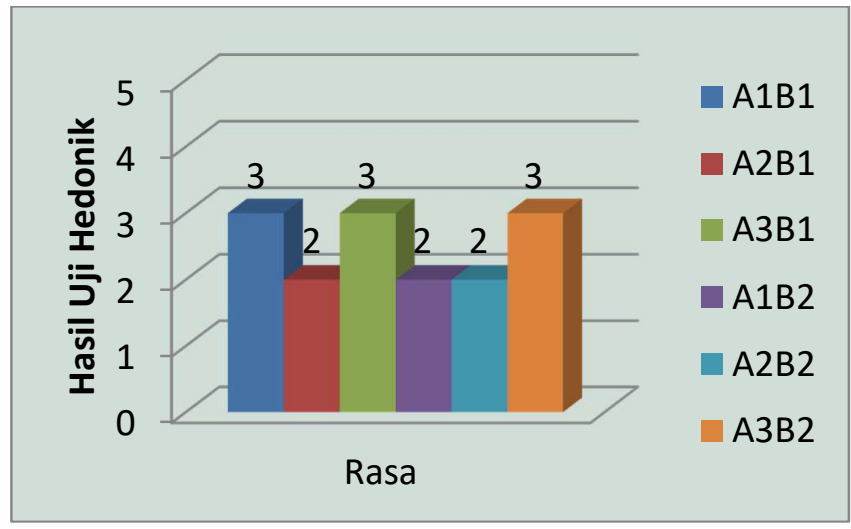

Gambar 7. Uji Hedonik Rasa Enhalus Tea 
Hasil analisis uji hedonic menunjukkan bahwa panelis memilih kategori agak suka terhadap rasa minuman Enhalus Tea formula A1B1, A3B1, A3B2 dibandingkan dengan formula A2B1, A1B2, A2B2 pada kategori kurang suka (Gambar 7). Hal ini berarti bahwa panelis lebih memilih rasa minuman Enhalus Tea yang berasal dari daun muda dan tua dengan cara pengeringan dianginkan serta daun tua dengan cara dioven. Penelitian Ulandari dkk (2019) menunjukkan bahwa suhu pengeringan dapat mempengaruhi tingkat kesukaan panelis terhadap rasa teh. Pengeringan dengan cara diangin-anginkan membutuhkan suhu ruang dan hempasan angin untuk membuat daun lamun menjadi kering, sedangkan pengeringan menggunakan oven membutuhkan suhu $60^{\circ} \mathrm{C}$. Oleh karena itu suhu pengeringan menggunakan oven lebih tinggi dari suhu dengan cara diangin-anginkan.

Menurut Rifqi dkk., (2017), bahwa aroma merupakan salah satu indikator yang mempengaruhi kesukaan panelis terhadap produk pangan. Lebih lanjut menurut Winarno (1993), bahwa aroma daun teh disebabkan karena adanya senyawa aromatik yang mudah menguap, adanya proses ekstraksi komponen kimia teh herbal seperti karbohidrat, protein, gugus reduksi gula saat teh diseduh, serta adanya oksidasi senyawa polifenol dan turunannya seperti katekin menjadi theaflavin dan theaburigin yang memberikan aroma yang khas. Komponen aromatik minuman Enhalus Tea pada daun setengah tua dan cara pengeringan dianginkan tetap terjaga sehingga ketika diseduh komponen tersebut menghasilkan aroma yang lebih kuat dibandingkan formula lainnya.

Rasa minuman Enhalus Tea agak kuat terdapat pada formula A2B1, A1B1, diikuti oleh formula A3B1, A2B2, dan formula A1B2, dan A3B2. Formula minuman Enhalus Tea dengan cara diangin-anginkan mempunyai rasa agak kuat lebih besar apabila dibandingkan formula yang dikeringkan dengan cara dioven. Menurut Angraiyati dan Hamzah (2017) menurunnya rasa sepat disebabkan kadar polifenol semakin berkurang dengan bertambahnya waktu proses pengeringan yang semakin lama dimana kadar polifenol akan memberikan rasa sepat pada seduhan dan bubuk teh herbal yang dihasilkan. Pada penelitian minuman Enhalus Tea ini, daun yang dikeringkan dengan cara dioven, kanudngan flavonoid semakin berkurang akibat pemanasan pada oven, sehingga rasa minuman lebih sedikit dibandingkan dengan minuman Enhalus Tea yang diangin-anginkan. Menurut Saragih (2014) rasa bahan pangan merupakan salah satu parameter penting yang mempengaruhi penerimaan konsumen terhadap suatu produk pangan. Rasa yang dihasilkan oleh panelis dipengaruhi oleh komponen yang ada di dalam bahan dan proses dari minuman Enhalus Tea. Rasa menjadi faktor yang sangat menentukan pada putusan akhir konsumen untuk menolak atau menerima suatu makanan, walau parameter penilaian yang lain lebih baik, jika rasa makanan tidak disukai maka produk akan ditolak. Menurut SNI 3836 (2013) rasa seduhan teh yang baik adalah khas produk teh. Minuman Enhalus Tea telah menunjukkan rasa khas produk daun lamun Enhalus acoroides.

\section{Kesimpulan}

Dari hasil penelitian dapat disimpulkan berdasarkan analisis data pada uji deskripsi sensori aroma kuat dimiliki oleh sampel A2B1 (daun setengah tua-dianginkan). Penilaian warna pada semua sampel rerata berada di tingkat 1 yaitu hijau kekuningan. Sedangkan penilaian rasa terkuat pada sampel A2B1 (daun setengah tuadianginkan) karena adanya senyawa tanin pada daun teh.

Berdasarkan analisis data pada pengukuran uji hedonik pada uji organoleptik Enhalus Tea yang paling disuka adalah pada sampel A3B1 (daun tua dengan cara pengeringan dianginkan) dengan rerata nilai aroma, warna dan rasa adalah 3 .

\section{Daftar Pustaka}

Aryadi, Fadli, dkk. 2017. Analisis Organoleptik Produk Teh Celup Tawaloho (Spondias pinnata). Universitas Halu Oleo, Kendari

Ginting, Roy B., dkk. 2015. Tingkat Kesukaan Masyarakat Terhadap Teh Daun Gaharu (Aquilaria mallacensis Lamk.) Dibandingkan Teh Lain yang Beredar di Pasaran. Universitas Sumatera Utara

Hutabarat, Lusiana R. 2017. Aktivitas Antioksidan dan Bioaktif dari Ekstrak Lamun E. acoroides. Universitas Maritim Raja Ali Haji.

Irawan, Henky. 2014. Ekstraksi Senyawa Metabolit Sekunder Lamun Thalassodendron ciliatum Pada Pelarut Berbeda. Universitas Maritim Raja Ali Haji.

Irawan, A., dan Matunkotta, C. 2015. Enhalus acoroides: Lamun Terbesar di Dunia. Oseana, 11(1): 19-26. 
Latuihamallo, Y., Watuguly, T., \& Tuapattinaya, P. 2019. Kualitas Susu Berbahan Dasar Biji Lamun Jenis Enhalus acoroides: Penentuan Nilai Viskositas dan Pengujian Sifat Mikrobiologi di Laboratorium. BIOPENDIX: Jurnal Biologi, Pendidikan Dan Terapan, 5(2), 119-129.

Lin-Xiangyang, Zhang-Lijing, Lei-Hanwu, Zhang-Hong, Cheng-Yanling, Zhu-Rongbi , Ruan- Roger. 2010. Effect of drying technologies on quality of green tea. International Agricultural Engineering Journal, 19(3):30-37.

Muskitta, M., \& Tuapattinaya, P. 2019. Analisis Kadar Protein Pada Acoroides Milk Berdasarkan Suhu Dan Lama Penyimpanan. BIOPENDIX: Jurnal Biologi, Pendidikan Dan Terapan, 2(2), 133-139.

Mudau, F.N. and W. Ngezimana, 2014. Effect of different drying methods on chemical composition and antimicrobial activity of bush tea (Athrixia phylicoides). International Journal of Agriculture \& Biology, 16(5): 1011-1014.

Owuor, P.O. dan Obanda, M. 2001. Comparative responses in plain black tea quality parameters of different tea clones to fermentation temperature and duration. Food Chem., 72(3): 319-327.

Padang, A. 2011. Struktur Komunitas Diotom Bentik yang Epifit pada Daun Lamun. Bimafika. Volume 3, Nomor $225-229$.

Phillips, R.C., dan Milchakova, N.A., Kovalevsky, A.O. 2003. Seagrass Ecosystems. Institute of Biology of the southern Seas, National Academy of Sciences of Ukraine, Sevastopol, Ukraine. МОРСЬКИЙ ЕКОЛОГІЧНИЙ ЖУРНАЛ, 2(2):29-39.

Rahakbauw, I.D. 2016. Analisis Senyawa Flavonoid Daun Lamun Enhalus acoroides di Perairan Pantai Desa Waai Kabupaten Maluku Tengah. Universitas Pattimura. Skripsi. Ambon.

Rizkia, P. 2014. Uji Efektivitas Antioksidan Ekstrak Etanol 70\%, Ekstrak dan Isolat Senyawa Flavonoid dalam Umbi Binahong (Anredera cordifolia (Ten.) Steenis). UIN Maulana Malik Ibrahim Malang.

Rohdiana, Dadan. 2015. Teh: Proses, Karakteristik dan Komponen Fungsionalnya. Pusat Penelitiaan Teh dan Kina (Research Institute for Tea and Cinchona).

Sjafrie, Nurul D.M., dkk. 2018. Status Padang Lamun Indonesia 2018. Pusat Penelitian Oseanografi.

Susiwi. 2009. Penilaian Organoleptik. Universitas Pendidikan Indonesia.

Tuapattinaya, P.M.J. 2014. Hubungan Faktor Fisik Kimia Lingkungan dengan Keanekaragaman Lamun (seagrass) di Perairan Pantai Desa Suli. Biologi Sel: Jurnal Biology Science \& Education, 3(1): 54-67

Tehubijuluw, H., Watuguly, T., \& Tuapattinaya, P. 2018. Analisis Kadar Flavonoid Pada Teh Daun Lamun (Enhalus acoroides) Berdasarkan Tingkat Ketuaan Daun. BIOPENDIX: Jurnal Biologi, Pendidikan dan Terapan, 5(1), 1-7.

Tuapattinaya, P.M.J., Watuguly, Th. W., Kurnia, T.S. 2018. Analysis of vitamin B12 level and organoleptic test in Tempe made from seagrass seeds Enhalus acoroides based on the various addition of yeast volume, Proceeding Book The 3rd International Seminar on Education, 2(2018):131-148. 